\title{
Metabolic balance of gross primary production and community respiration in Sagami Bay, Japan
}

\author{
Shinji Hashimoto ${ }^{1,4, *}$, Naho Horimoto ${ }^{2}$, Takashi Ishimaru ${ }^{2}$, Toshiro Saino ${ }^{1,3}$ \\ ${ }^{1}$ Japan Science and Technology Agency, c/o Hydrospheric Atmospheric Research Center, Nagoya University, Chikusa-ku, \\ Furo-cho, Nagoya 464-8601, Japan \\ ${ }^{2}$ Tokyo University of Marine Science and Technology, 4-5-7, Kohnan, Minato-ku, Tokyo 108-8477, Japan \\ ${ }^{3}$ Hydrospheric Atmospheric Research Center, Nagoya University, Chikusa-ku, Furo-cho, Nagoya 464-8601, Japan
}

${ }^{4}$ Present address: Kosei High School, 1-17-2, Takabayashi, Hamamatsu, Shizuoka 430-0907, Japan

\begin{abstract}
Gross primary production (GPP), community respiration (CR) and net community production (NCP) were studied for about 3 yr (September 2001 to June 2004) within the euphotic layer in the center of Sagami Bay, Japan. Oxygen fluxes exhibited seasonal and annual variations linked to the seasonal cycle of water column conditions and solar irradiance. GPP was $>1 \mathrm{mmol} \mathrm{O}_{2} \mathrm{~m}^{-3} \mathrm{~d}^{-1}$ above ca. $30 \mathrm{~m}$ in summer. CR exhibited seasonal patterns coupled to the variation in GPP. NCP at the surface was generally positive and maximum throughout the observation period, whereas at the subsurface layer it was negative, suggesting a balanced relationship between production and consumption of oxygen in the euphotic zone. GPP, CR and NCP integrated within the euphotic zone ranged from 44 to 264 (mean \pm SE: $111 \pm 13), 10$ to $311(100 \pm 15)$ and -94 to $112(11 \pm 8) \mathrm{mmol} \mathrm{O}_{2} \mathrm{~m}^{-2}$ $\mathrm{d}^{-1}$, respectively. GPP and CR showed distinct seasonal patterns, and both tended to be higher from spring to summer (high productivity, HP) than from fall to winter (low productivity, LP). The threshold GPP for metabolic balance of the community (i.e. GPP:CR, $P: R=1$ ) was higher during the HP period (4.1 mmol O $\left.\mathrm{m}_{2} \mathrm{~m}^{-3} \mathrm{~d}^{-1}\right)$ than during the LP period $\left(0.4 \mathrm{mmol} \mathrm{O}_{2} \mathrm{~m}^{-3} \mathrm{~d}^{-1}\right)$, with a mean value of $1.4 \mathrm{mmol} \mathrm{O}_{2} \mathrm{~m}^{-3} \mathrm{~d}^{-1}$. These results suggest the importance of organic carbon produced in the past or elsewhere in sustaining a relatively high background CR rate during the HP period in Sagami Bay.
\end{abstract}

KEY WORDS: Gross primary production - Community respiration - Net community production · Seasonal variation · Sagami Bay

Resale or republication not permitted without written consent of the publisher

\section{INTRODUCTION}

Carbon exchange by photosynthesis and respiration is the largest biogeochemical cycle in aquatic systems. Almost all estimates of oceanic primary production have been obtained by the ${ }^{14} \mathrm{C}$ tracer in vitro incubation technique (Steemann-Nielsen 1952). While this technique gives an approximate estimate of primary production, it does not give any information on heterotrophic processes by microorganisms, which play an important role in carbon cycles via microbial food webs (Azam et al. 1983). However, oxygen-based measurements offer a unique insight into physiological and biogeochemical processes that other tracers cannot provide.
The metabolic balance between gross primary production (GPP) and community respiration (CR) determines the net community production (NCP). It is very important to investigate the metabolic balance since the processes of GPP and CR are responsible for major flows of carbon in the upper waters of most aquatic systems. The balance between GPP and CR in oceanic systems determines whether the biological pump acts as a net source or sink of carbon (Williams 1993). However, this balance is variable on geographical, temporal and seasonal scales (del Giorgio et al. 1997, Geider 1997, Duarte \& Agustí 1998, Williams 1998, del Giorgio \& Duarte 2002), highlighting the need for ecosystem functioning over smaller scales to be studied in order to determine the trophic status on a global scale (Serret et al. 1999, González et al. 2001). 
The GPP threshold (i.e. GPP at GPP = CR) separates the net autotrophic from net heterotrophic communities. The threshold is affected greatly by the heterotrophic respiratory rate. When bacterial and protozoan respiratory rates are low, the threshold becomes low. The threshold is relatively high $\left(50 \mathrm{mmol} \mathrm{O}_{2} \mathrm{~m}^{-3} \mathrm{~d}^{-1}\right)$ in coastal regions, whereas in the open sea it is relatively low $\left(<3 \mathrm{mmol} \mathrm{O}_{2} \mathrm{~m}^{-3} \mathrm{~d}^{-1}\right.$ ) (Duarte \& Agustí 1998, González et al. 2001, Serret et al. 2001, Agustí et al. 2004, Agustí \& Duarte 2005). Recently, Duarte et al. (2004) reported a value of about $4 \mathrm{mmol} \mathrm{O}_{2} \mathrm{~m}^{-3} \mathrm{~d}^{-1}$ in a Spanish coastal area of the northwestern Mediterranean. However, knowledge about variation of the seasonal threshold is meager. It is also important to evaluate the depth of compensation irradiance (percentage irradiance at $\mathrm{NCP}=0$ ) related to the GPP threshold (Agustí \& Duarte 2005).

Some studies on NCP succession have monitored GPP and CR in time series >1 yr (Smith \& Kemp 2001, Berman et al. 2004, Duarte et al. 2004). Time series of the metabolism in productive coastal communities have shown that GPP and CR may be in balance over annual time scales (Sherr \& Sherr 1996, Serret et al. 1999). Recently, it has been reported that the metabolic status of ecosystems also reflects net heterotrophy in coastal regions (Duarte et al. 2004). However, these studies have been carried out in areas very close to the shore, under eutrophic conditions, or under strong tidal influence within estuaries or fjords, situations well removed from steady-state conditions. Furthermore, some studies were restricted only to surface NCP measurements (e.g. Blight et al. 1995).

The seasonal variability of heterotrophic metabolism may be coupled to that of primary production (Duarte et al. 2004, Agustí \& Duarte 2005), while others report no evidence of this coupling (Findlay et al. 1991, Agustí et al. 2004). The decoupling between CR and GPP is possibly related to the physical condition of the water column and/or to organic inputs.

Here, we present data on the spatial and temporal variations of GPP, CR and NCP within the euphotic zone over about $3 \mathrm{yr}$ in the center of Sagami Bay, and examine the relationships between these parameters. We show that the photic zone of the bay has a net autotrophic character for most of the year, with a brief period of net heterotrophy in late spring and/or summer.

\section{MATERIALS AND METHODS}

Study area. Sagami Bay, situated on the eastern coast of Japan, covers an area of $2700 \mathrm{~km}^{2}$, with a mean depth of $750 \mathrm{~m}$ (Fig. 1). Fresh water flows into Sagami Bay from 2 main rivers (Sagami and Sakawa) and other minor rivers. The amount of fresh water is greater in summer $\left(7\right.$ to $\left.10 \times 10^{6} \mathrm{~m}^{3} \mathrm{~d}^{-1}\right)$ than in winter ( 3 to $5 \times 10^{6} \mathrm{~m}^{3} \mathrm{~d}^{-1}$ ) (Iwata 1985). Counterclockwise currents along the coast are dominant in the bay, independent of the season.

Sampling. Time-series observations were carried out monthly from September 2001 to June 2004 at Stn S3 in the center of Sagami Bay by the RV 'Seiyo Maru' of the Tokyo University of Marine Science and Technology and the RV 'Tansei Maru' of the Japan Agency for MarineEarth Science and Technology (Fig. 1). Hydrographic data (water temperature, salinity) and water samples were collected with a CTD (Falmouth Scientific) rosette system fitted with Teflon-coated Niskin bottles of 81 capacity. The vertical photosynthetically active radiation (PAR) profiles were measured using a natural fluorescence sensor (PNF 2300, Biospherical Instruments). The samples for determination of GPP were collected from the depths corresponding to $100,30,20,10,5$, and 1 or $0.2 \%$ of the surface irradiance with reference to the PAR profile. The seawater samples for nutrient concentration analysis were collected from 9 depths above $100 \mathrm{~m}$. The incident solar radiation was monitored with a LiCor 2 sensor during the incubation experiments.

Chlorophyll a. A total of 200 to $300 \mathrm{ml}$ samples were filtered onto $25 \mathrm{~mm}$ Whatman GF/F filters under gentle aspiration $(<250 \mathrm{kPa})$. Chlorophyll a (chl a) was immediately extracted by immersing the filter in $N, N$ dimethylformamide (Suzuki \& Ishimaru 1990), and the samples were preserved at $-20^{\circ} \mathrm{C}$ until on-shore analysis. Chl a concentrations were determined using a Turner Design Model 10-AU fluorometer calibrated with commercial chl a (Wako Pure Chemical Industries), according to the method of Parsons et al. (1984). Euphotic-zone-integrated standing stocks were obtained by trapezoidal integration to the depth of $1 \%$ surface incident irradiance.

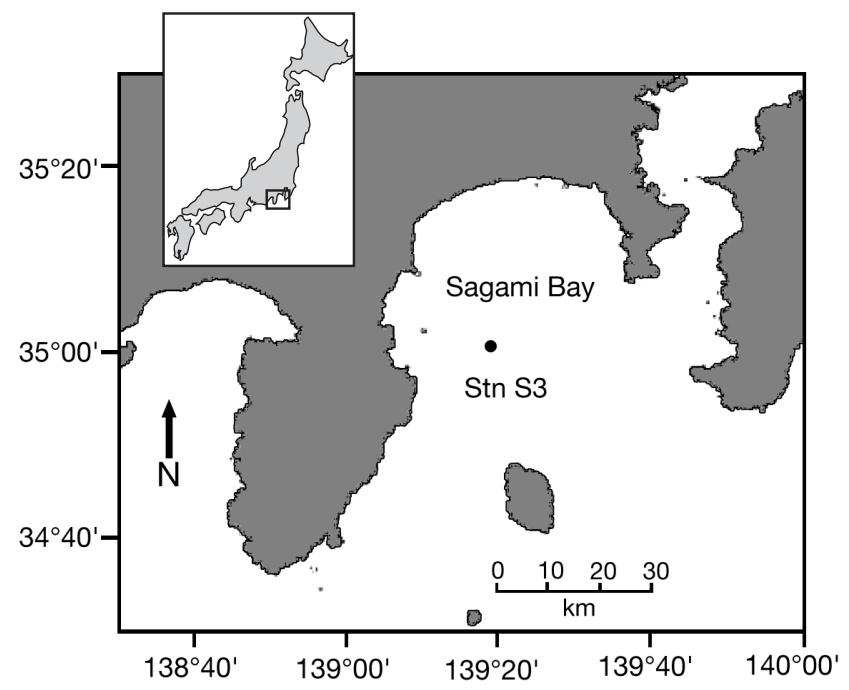

Fig. 1. Sampling location in Sagami Bay, Japan 
Nitrate + nitrite and phosphate. Samples were collected in polystyrene bottles, frozen immediately after collection and stored at $-20^{\circ} \mathrm{C}$ until analysis. Nitrate + nitrite and phosphate concentrations were measured with a Bran and Luebbe AACS III.

GPP, CR and NCP. GPP and CR were determined from in vitro changes in dissolved oxygen after $24 \mathrm{~h}$ light and dark bottle incubations. Seawater was carefully siphoned into nine $100 \mathrm{~cm}^{3}$ gravimetrically calibrated borosilicate glass bottles from the Niskin bottle by means of a silicone tube. From each depth, 3 dark bottles and 3 light bottles were incubated for $24 \mathrm{~h}$ in an on-deck incubator that simulated the irradiance at the original sampling depths by use of various combinations of neutral density and blue plastic filters. The deck incubator was equipped with a cooling and heating system so as to keep the water temperature within $\pm 0.5^{\circ} \mathrm{C}$ during incubation. During hours of darkness, the incubators were covered with opaque screens to prevent artifacts due to the ship's deck light. The dark bottles were wrapped with aluminum foil and were kept within dark bags, and the light bottles were incubated under irradiance conditions that simulated those of the original sampling depth. After incubation, the light and dark bottles were fixed immediately. Fixing and storage, reagents and standardization followed the recommendations of Carritt \& Carpenter (1966). Dissolved oxygen concentration was measured by automated precision Winkler titration performed with a Metrohm 785 DMP Titrino, utilizing a potentiometric end point (Oudot et al. 1988). The average coefficient of variation $(\mathrm{CV})$ of the dissolved oxygen concentration in triplicated bottles was about $0.05 \%$. Euphotic-zoneintegrated values were calculated as the standing stock of chl a. CR was determined from the oxygen change in the dark bottles, NCP was determined from the oxygen change in the light bottles, and GPP was calculated as the sum of CR and NCP.

\section{RESULTS}

\section{Physicochemical condition}

Comparison of PAR from September 2001 to August 2002, September 2002 to August 2003 and September 2003 to June 2004 showed lower values in June/July 2003 than in June/July of the other years (Fig. 2). PAR in June/July 2003 was equal to that in winter. The surface temperature ranged from 15 to $27^{\circ} \mathrm{C}$ and was $>20^{\circ} \mathrm{C}$ in May/June to October (summer) and about $15^{\circ} \mathrm{C}$ from January to March (winter) (Fig. 3a,b). Water mass of high temperature-low salinity was present at the surface in summer and low temperature-high salinity in winter. In summer, the thermocline was at 20 to $40 \mathrm{~m}$, while in winter the depth of the upper mixed layer deepened by $>100 \mathrm{~m}$. This was similar to the data reported previously for Sagami Bay (Kamatani et al. 1981, Kanda et al. 2003). The low salinity in the surface layer in summer is thought to be due to the influence of riverine water, as mentioned in the 'Introduction'. Regional upwelling was sporadically observed in October 2001, June/July and November 2002, July/ August 2003 and May 2004 (Fig. 3a). Takahashi et al. (1980) reported that local upwelling occurs in Sagami Bay. The euphotic layer and upper mixed layer were found at depths of 30 to 67 and 10 to $131 \mathrm{~m}$, respectively. The euphotic layer depth tended to be deeper than the upper mixed layer depth from spring to summer and shallower from fall to winter.

Nitrate + nitrite concentrations were $>5 \mu \mathrm{mol} \mathrm{l}^{-1}$ during fall to winter in the water column, while the concentrations were $<1 \mu \mathrm{mol} \mathrm{l}^{-1}$ in the upper $20 \mathrm{~m}$ during spring to summer (Fig. 3c). In particular, the concentrations were $<0.5 \mu \mathrm{mol} \mathrm{l}^{-1}$ in the upper $10 \mathrm{~m}$ from June to October 2002 and in the upper 20 m from May to September 2003. This is due to the seasonal thermocline that suppresses vertical mixing. The nitrate + nitrite concentration of $>5 \mu \mathrm{mol}{ }^{-1}$ was brought to the vicinity of $40 \mathrm{~m}$ by upwelling in October 2001, June/July and November 2002 and July 2003 (Fig. 3c). The distributions of spatial and temporal variations in phosphate concentrations were also similar to those of nitrate + nitrite concentrations (Fig. 3d). However, phosphate concentrations $>0.05 \mu_{\mathrm{mol} \mathrm{l}} \mathrm{l}^{-1}$ were in the upper $10 \mathrm{~m}$, where nitrate + nitrite concentrations were $<0.5 \mu \mathrm{mol}$ $\mathrm{l}^{-1}$, indicating that $\mathrm{N}: \mathrm{P}$ ratios were $<16$.

The percentage of oxygen saturation ( $\% \mathrm{O}_{2}$ sat.) in the upper layer is a valuable indicator broadly summarizing the recent history of biological activity (Najjar \& Keeling 1997). High levels of $\% \mathrm{O}_{2}$ sat. (>100\%) were observed near the surface in summer (Fig. 4a). Low levels of $\% \mathrm{O}_{2}$ sat. (<100\%) were found in subsurface waters in summer and in the water column during fall to spring, when the surface mixed layer was deep (Fig. 4a).

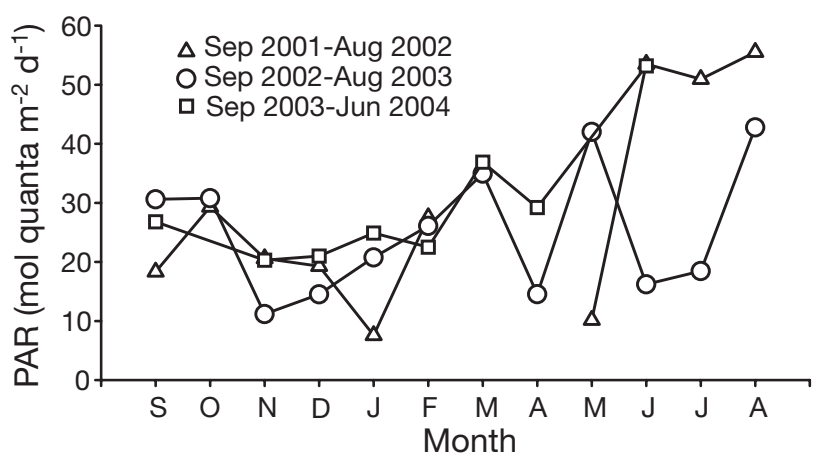

Fig. 2. Seasonal variation in photosynthetically active radiation (PAR) at Stn S3 in Sagami Bay 


\section{Phytoplankton biomass}

Chl a concentrations reached values $>1.5 \mathrm{mg} \mathrm{m}^{-3}$ in the subsurface layer in June/July and November 2002, June to October 2003 and April to June 2004 (Fig. 4b).
The fluctuation of chl a vertically integrated in the euphotic zone was irregular and did not show obvious seasonal variation (Kamatani et al. 1981) (Fig. 5). The mean value of chl a from September 2003 to June 2004 was the highest among the 3 studied years (Table 1).
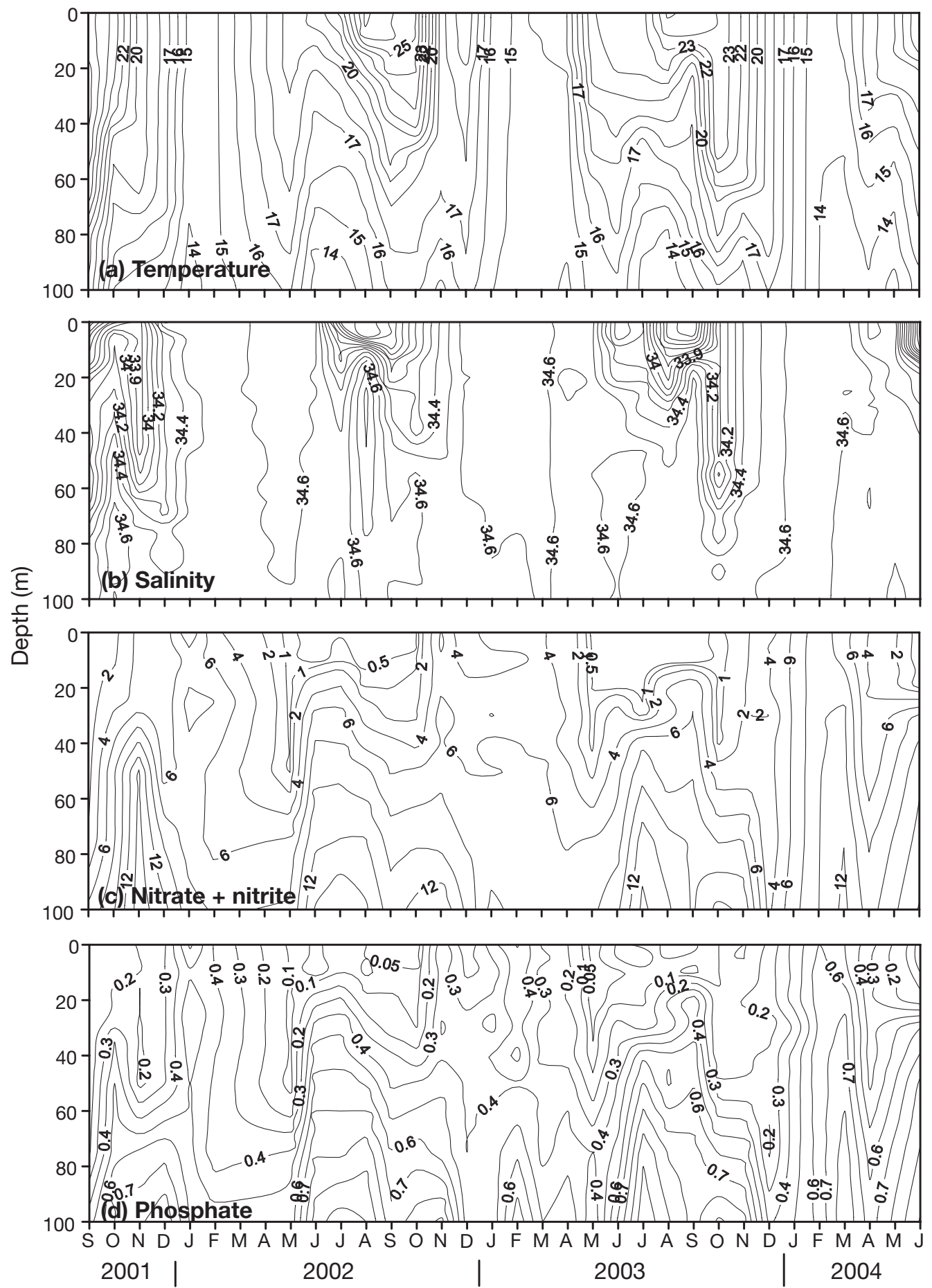

Fig. 3. Vertical and temporal distribution of (a) temperature $\left({ }^{\circ} \mathrm{C}\right)$, (b) salinity, (c) nitrate + nitrite concentrations $\left(\mu \mathrm{mol} \mathrm{l}^{-1}\right)$ and (d) phosphate concentrations $\left(\mu \mathrm{mol} \mathrm{l}^{-1}\right.$ ) from September 2001 to June 2004 


\section{Oxygen flux and $P: R$ balance}

GPP ranged from 0.1 to $50.2 \mathrm{mmol} \mathrm{O}_{2} \mathrm{~m}^{-3} \mathrm{~d}^{-1}$ within the euphotic layer during the observed period (Fig. 4c). Generally, GPP was $>1 \mathrm{mmol} \mathrm{O}_{2} \mathrm{~m}^{-3} \mathrm{~d}^{-1}$ above ca. $30 \mathrm{~m}$ in summer. The spatial and temporal variations in GPP normalized to chl a concentration were also similar to that of GPP (data not shown). GPP and $\% \mathrm{O}_{2}$ sat. were positively related $(t$-test, $\mathrm{p}<0.001)$. This result reveals that the oxygen supersaturation at
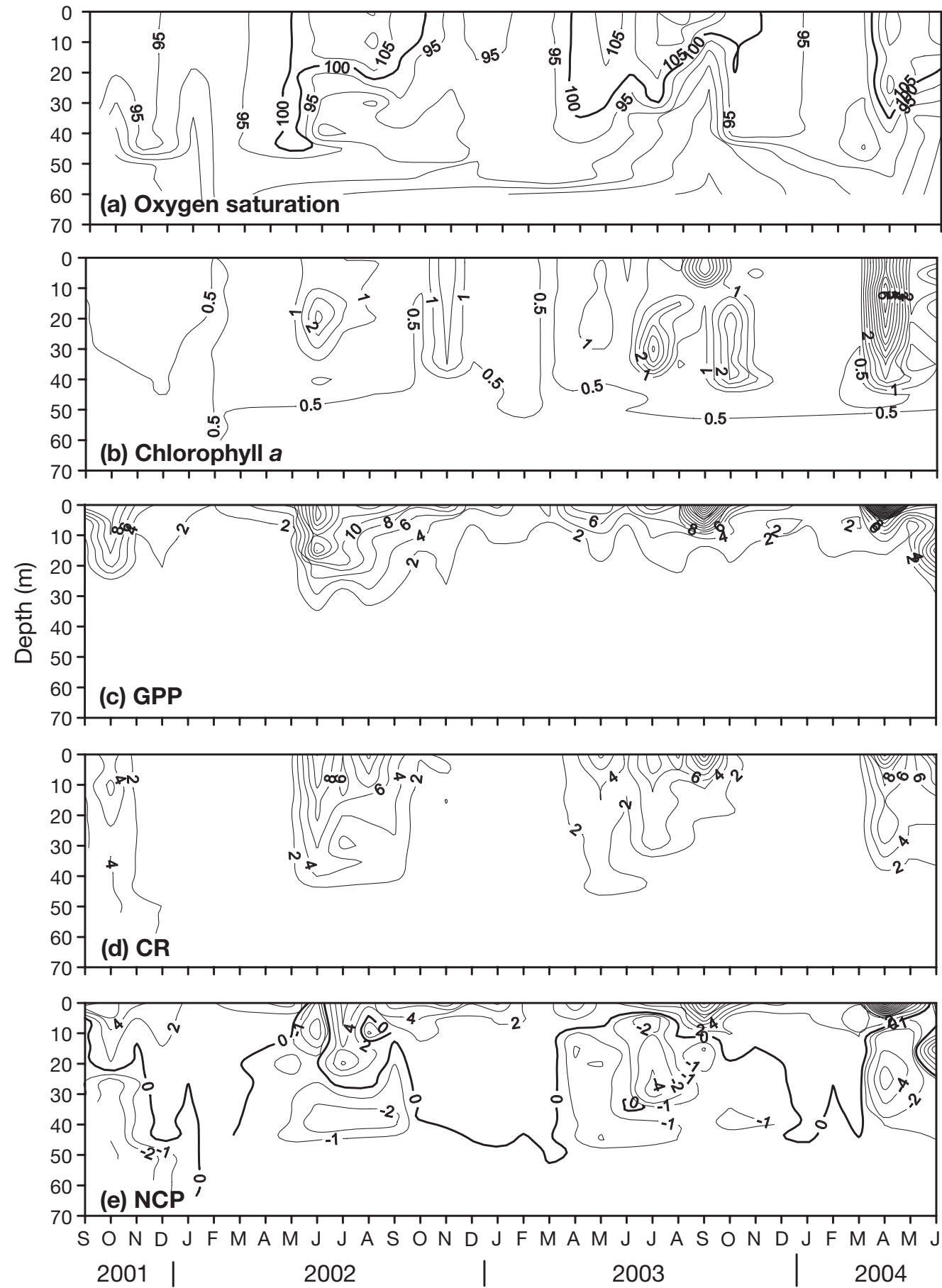

Fig. 4. Vertical and temporal distributions of (a) percentage of oxygen saturation (\%), (b) chlorophyll a concentration (mg $\mathrm{m}^{-3}$ ), (c) gross primary production (GPP; mmol $\left.\mathrm{O}_{2} \mathrm{~m}^{-3} \mathrm{~d}^{-1}\right)$, (d) community respiration $\left(\mathrm{CR}_{i} \mathrm{mmol} \mathrm{O}_{2} \mathrm{~m}^{-3} \mathrm{~d}^{-1}\right)$ and (e) net community production ( $\mathrm{NCP} ; \mathrm{mmol} \mathrm{O}_{2} \mathrm{~m}^{-3} \mathrm{~d}^{-1}$ ) from September 2001 to June 2004 


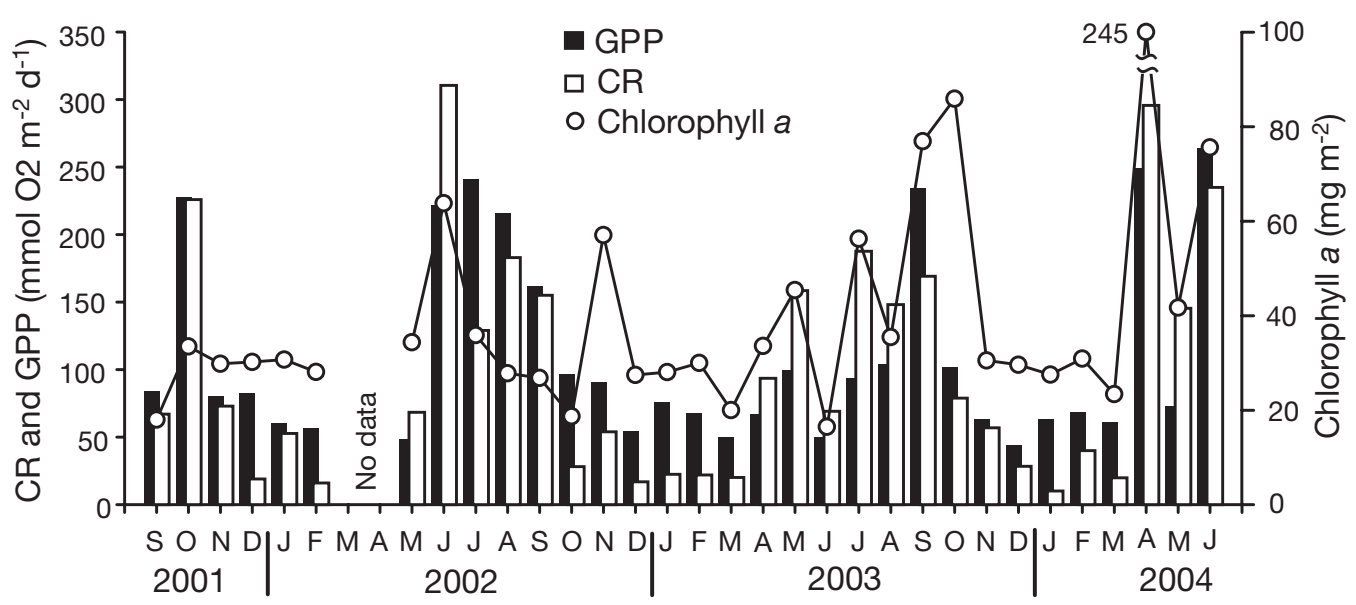

Fig. 5. Temporal variations in vertically integrated chlorophyll a, gross primary production (GPP), and community respiration (CR) from September 2001 to June 2004

the surface is partially due to the photosynthetically produced oxygen by phytoplankton.

CR exhibited seasonal patterns coupled to the variation in GPP (Fig. 4d). CR generally showed maximum values at the surface, and was $>1 \mathrm{mmol} \mathrm{O}_{2} \mathrm{~m}^{-3} \mathrm{~d}^{-1}$ from spring to fall, while it was $<1 \mathrm{mmol} \mathrm{O}_{2} \mathrm{~m}^{-3} \mathrm{~d}^{-1}$ in winter throughout the euphotic zone (Fig. 4d). In Fig. 4e, zero represents community compensation depth (CCD). $\mathrm{CCD}$ was relatively deep in winter (ca. $50 \mathrm{~m}$ ) and shallow from spring to fall (10 to $30 \mathrm{~m}$ ). NCP was generally positive and showed maximum values at the surface throughout the observation period (Fig. 4e). In contrast, NCP in the subsurface layer was negative. In particular, when GPP was $>10 \mathrm{mmol} \mathrm{O}_{2} \mathrm{~m}^{-3} \mathrm{~d}^{-1}$ at the surface, NCP was $<-1 \mathrm{mmol} \mathrm{O}_{2} \mathrm{~m}^{-3} \mathrm{~d}^{-1}$ in the subsurface layer (Fig. 4e).

GPP and CR vertically integrated in the euphotic zone showed distinct seasonal patterns, and both tended to be higher from spring to summer (April to October) than from fall to winter (November to March) (Fig. 5). The seasonal trend of CR generally coincided with that of GPP. There were a few months in which CR exceeded GPP even when GPP was $>100 \mathrm{mmol} \mathrm{O}_{2}$ $\mathrm{m}^{-2} \mathrm{~d}^{-1}$. The mean values of GPP and CR from September 2001 to August 2002 were the highest of the 3 studied years (Table 1). Hence, the experimental time was separated into a high-productivity (HP) period (April to October) and a low-productivity (LP) period (November to March). The mean values of GPP and CR in the HP period from September 2003 to June 2004 were the highest of the 3 studied years (Table 2). The mean values of CR during the HP period were higher than those of GPP from September 2002 to August 2003 and September 2003 to June 2004, though GPP from September 2001 to August 2002 was slightly higher than CR (Table 2). The difference in mean values of GPP during the HP periods between September 2002 to August 2003 and September 2003 to June 2004 was $88 \mathrm{mmol} \mathrm{O}_{2} \mathrm{~m}^{-2} \mathrm{~d}^{-1}$, while that of CR was $65 \mathrm{mmol}$ $\mathrm{O}_{2} \mathrm{~m}^{-2} \mathrm{~d}^{-1}$. In contrast, the mean values of GPP during the LP period were higher than those of CR over the $3 \mathrm{yr}$ period and approximately equal, unlike those in the HP period (Table 2).

$\mathrm{NCP}$ was generally positive during summer-winter and negative in spring (Fig. 6). However, in 2003, NCP was negative not only in spring but also in summer. The mean value of NCP during the HP period over the 3 studied years was negative $\left(-6 \mathrm{mmol} \mathrm{O}_{2} \mathrm{~m}^{-2} \mathrm{~d}^{-1}\right)$, whereas that of the LP period was positive $(33 \mathrm{mmol}$ $\mathrm{O}_{2} \mathrm{~m}^{-2} \mathrm{~d}^{-1}$; Table 2).

The compensation irradiance (i.e. percentage irradiance at $P: R=1$ ) during the observed 3 yr period was

Table 1. Mean values $( \pm \mathrm{SE})$ of chlorophyll a $(\mathrm{chl} a)$, gross primary production (GPP), community respiration (CR) and net community production (NCP) calculated by trapezoidal integration from the surface to the $1 \%$ light depth

\begin{tabular}{|lcccc|}
\hline & Sep 2001-Aug 2002 & Sep 2002-Aug 2003 & Sep 2003-Jun 2004 & Sep 2001-Jun 2004 \\
\hline Chl a $\left(\mathrm{mg} \mathrm{m}^{-2}\right)$ & $33 \pm 4$ & $33 \pm 4$ & $52 \pm 9$ & $39 \pm 4$ \\
GPP $\left(\mathrm{mmol} \mathrm{O}_{2} \mathrm{~m}^{-2} \mathrm{~d}^{-1}\right)$ & $132 \pm 26$ & $84 \pm 9$ & $122 \pm 28$ & $111 \pm 13$ \\
$\mathrm{CR}\left(\mathrm{mmol} \mathrm{O}_{2} \mathrm{~m}^{-2} \mathrm{~d}^{-1}\right)$ & $114 \pm 31$ & $81 \pm 19$ & $108 \pm 31$ & $100 \pm 15$ \\
$\mathrm{NCP}\left(\mathrm{mmol} \mathrm{O}_{2} \mathrm{~m}^{-2} \mathrm{~d}^{-1}\right)$ & $17 \pm 17$ & $3 \pm 15$ & $14 \pm 14$ & $11 \pm 8$ \\
\hline
\end{tabular}




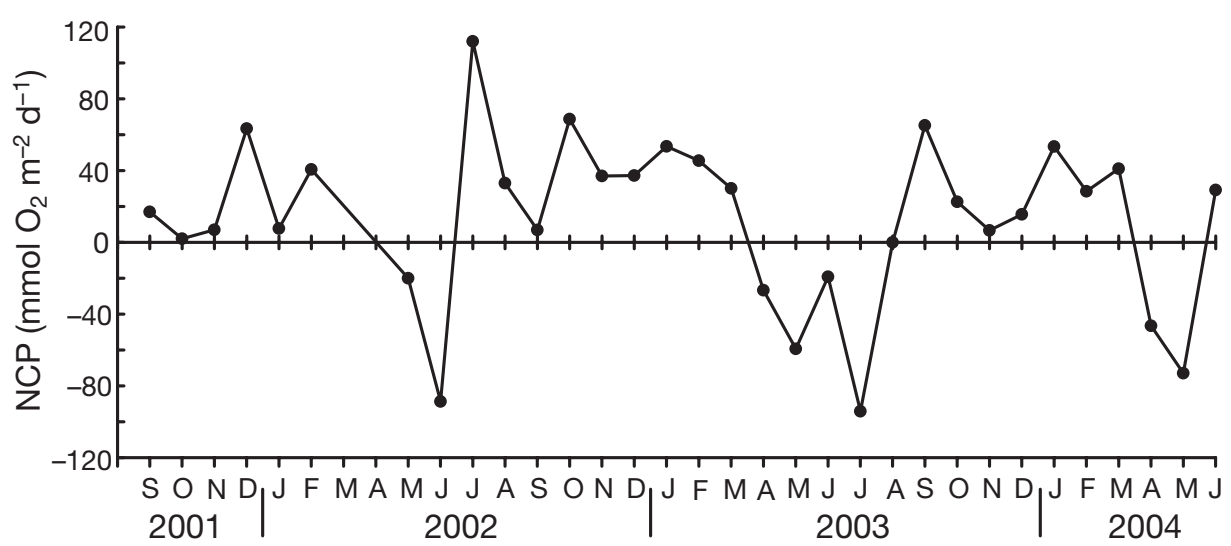

Fig. 6. Temporal variation in vertically integrated net community production (NCP) from September 2001 to June 2004

located at $8 \%$ of the ambient irradiance, and, during HP and LP, the percentage irradiance was 20 and $1 \%$, respectively (Fig. 7).

There was a positive relationship between the $P: R$ ratio and GPP (Fig. 8). An overall threshold GPP was $1.4 \mathrm{mmol} \mathrm{O}_{2} \mathrm{~m}^{-3} \mathrm{~d}^{-1}$, to reach a state of balanced metabolism (i.e. $P: R=1$ ), and, during $\mathrm{HP}$ and LP, the threshold GPP was 4.1 and $0.4 \mathrm{mmol} \mathrm{O}_{2} \mathrm{~m}^{-3} \mathrm{~d}^{-1}$, respectively.

\section{Annual fluxes of oxygen and $P: R$ balance}

In this study, annual GPP was higher than that in the Bay of Biscay and in the North Pacific subtropical gyre, whereas annual CR was approximately equal (Serret et al. 1999, Williams et al. 2004) (Table 3). Annual rates of GPP were higher than those of CR from September 2001 to August 2002 and September 2003 to June 2004, resulting in $P: R$ ratios of 1.3 and 1.2 , respectively. In contrast, GPP was nearly equal to CR from September 2002 to August 2003, resulting in a $P: R$ ratio of 1.0 . Therefore, annual NCP was not negative in the euphotic zone during the 3 yr period (Table 3 ).

\section{DISCUSSION}

In this study, a seasonal pattern was observed for GPP (Figs. 4c \& 5). GPP correlated positively with PAR ( $t$-test, $\mathrm{p}<0.01$ ). This implies that the rate of oxygen evolution is related to the light intensity. While the nitrate + nitrite concentrations were $<0.5 \mu_{\mathrm{mol}} \mathrm{l}^{-1}$ in the upper $10 \mathrm{~m}$ from May to October 2002 and in the upper $20 \mathrm{~m}$ from May to September 2003, the phosphate concentrations were $>0.05 \mu \mathrm{mol} \mathrm{l}^{-1}$ (Fig. 3c,d). However, GPP was higher relative to other periods. This suggests that phytoplankton growth is not greatly limited by nutrient concentrations in Sagami Bay. Nutrient concentrations, supporting relatively high GPP, may have been supplied from riverine water due to low salinity and a strong thermocline (Fig. 3a,b). The temporal variation in primary production is likely to be affected by light intensity and nutrient concentration in Sagami Bay.

The variations in CR are likely to be coupled to those in GPP from a dataset compiled from 100s of stations worldwide (e.g. Duarte \& Agustí 1998, Williams 1998), in contrast to reports that CR is independent of GPP because of the reduced bacterial and protozoan respiratory rates during periods of high phytoplankton

Table 2. Mean values $( \pm \mathrm{SE})$ of chl $a, \mathrm{GPP}, \mathrm{CR}$ and NCP during the high-productivity (April to October) and low-productivity (November to March) periods

\begin{tabular}{|lcccc|}
\hline & Sep 2001-Aug 2002 & Sep 2002-Aug 2003 & Sep 2003-Jun 2004 & Sep 2001-Jun 2004 \\
\hline High productivity & & & & $76 \pm 11$ \\
Chl a $\left(\mathrm{mg} \mathrm{m}^{-2}\right)$ & $36 \pm 7$ & $36 \pm 6$ & $184 \pm 45$ & $46 \pm 6$ \\
GPP $\left(\mathrm{mmol} \mathrm{O}_{2} \mathrm{~m}^{-2} \mathrm{~d}^{-1}\right)$ & $173 \pm 38$ & $96 \pm 14$ & $185 \pm 42$ & $146 \pm 20$ \\
$\mathrm{CR}\left(\mathrm{mmol} \mathrm{O}_{2} \mathrm{~m}^{-2} \mathrm{~d}^{-1}\right)$ & $164 \pm 43$ & $120 \pm 23 \pm 20$ & $-6 \pm 14$ \\
NCP $\left(\mathrm{mmol} \mathrm{O}_{2} \mathrm{~m}^{-2} \mathrm{~d}^{-1}\right)$ & $9 \pm 29$ & $-24 \pm 21$ & $0 \pm 29$ & $30 \pm 2$ \\
Low productivity & & $33 \pm 6$ & $28 \pm 1$ & $66 \pm 3$ \\
Chl $\left(\mathrm{mg} \mathrm{m}^{-2}\right)$ & $30 \pm 1$ & $68 \pm 7$ & $60 \pm 4$ & $32 \pm 5$ \\
GPP $\left(\mathrm{mmol} \mathrm{O}_{2} \mathrm{~m}^{-2} \mathrm{~d}^{-1}\right)$ & $70 \pm 6$ & $27 \pm 6$ & $31 \pm 7$ & $33 \pm 4$ \\
CR $\left(\mathrm{mmol} \mathrm{O}_{2} \mathrm{~m}^{-2} \mathrm{~d}^{-1}\right)$ & $40 \pm 12$ & $41 \pm 4$ & $29 \pm 8$ & 4 \\
NCP $\left(\mathrm{mmol} \mathrm{O}_{2} \mathrm{~m}^{-2} \mathrm{~d}^{-1}\right)$ & $30 \pm 12$ & & \\
\hline
\end{tabular}


production in Antarctic waters (Agustí et al. 2004). In Sagami Bay, the variations in CR generally coincided with that of GPP (Figs. 4c,d \& 5), suggesting a balanced relationship between production and consumption of oxygen in the euphotic zone of Sagami Bay, i.e. when GPP was relatively high, NCP was not relatively high (Figs. $5 \& 6$ ).

The CCD varied seasonally (Fig. 4e). The algal compensation depth (ACD) is conventionally taken as the depth to which $1 \%$ of the surface irradiance penetrates
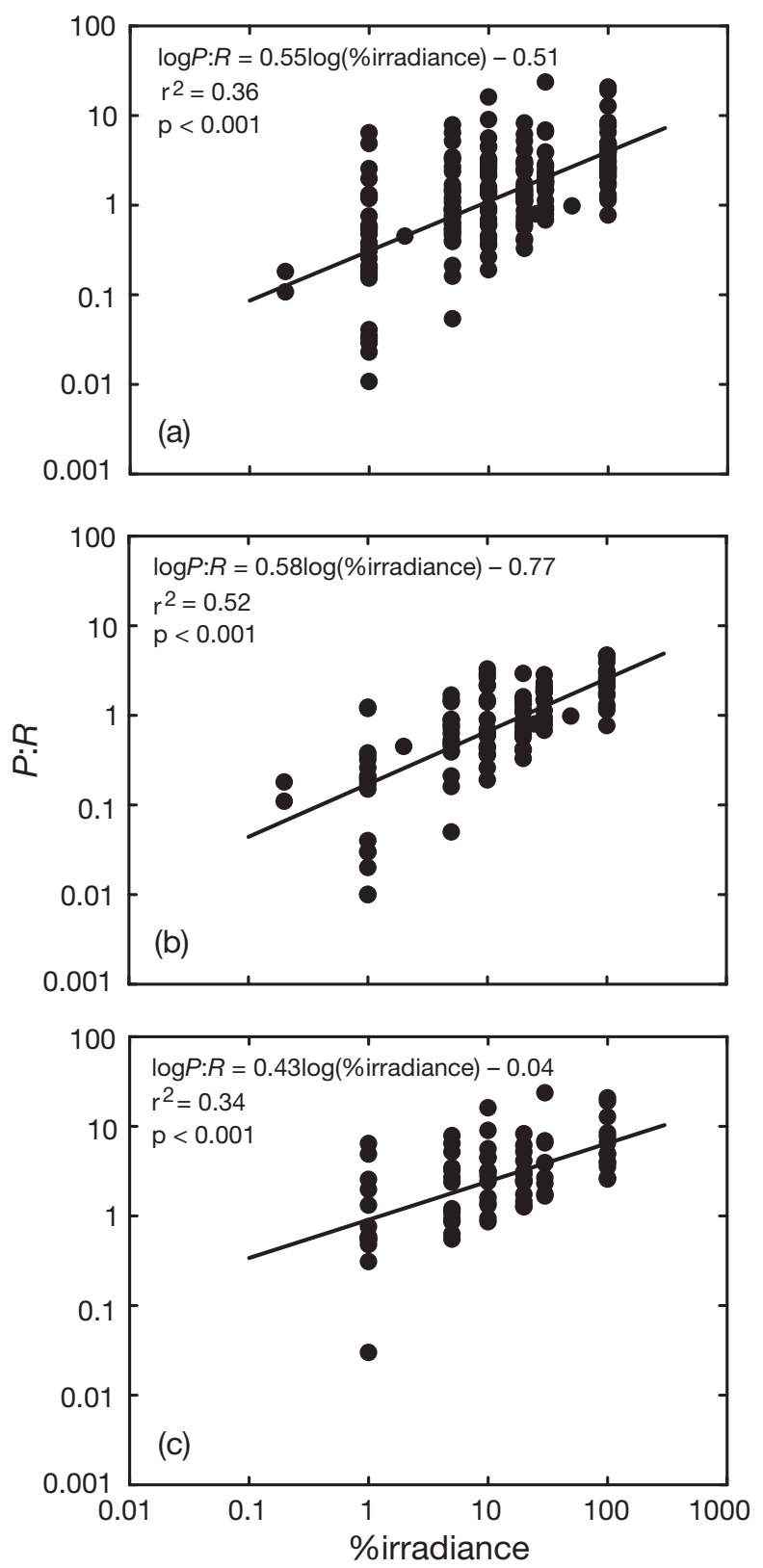

Fig. 7. Relationship between the $P: R$ ratio and the percentage of surface irradiance during (a) total, (b) high-productivity (April to October) and (c) low-productivity (November to March) periods (euphotic zone). Our observations of NCP allow us to determine the CCD. The difference between the 2 compensation depths is an expression of the relative contributions of algal and heterotrophic respiration (Williams \& Purdie 1991). Therefore, when heterotrophic respiration becomes more important than algal respiration, CCD becomes shallow. In contrast, when heterotrophic respiration becomes less important than algal respiration, $\mathrm{CCD}$ approaches the ACD. The CCD (1\% light depth: 40 to $50 \mathrm{~m}$ ) during the LP period was
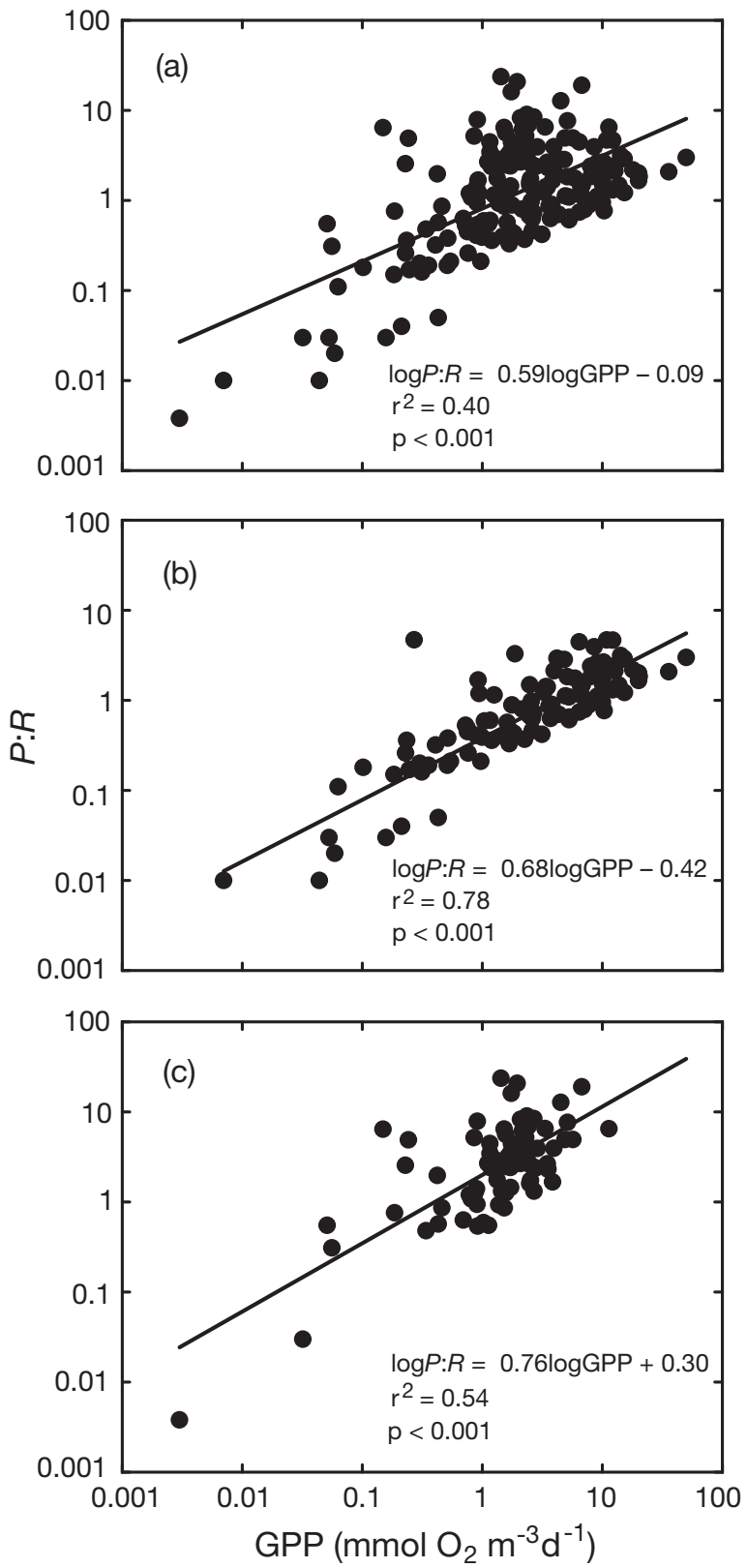

Fig. 8. Relationship between the $P: R$ ratio and the gross primary production (GPP) during (a) total, (b) high-productivity (April to October) and (c) low-productivity (November to March) periods 
Table 3. Annually integrated rates and mean values $( \pm \mathrm{SE})$ of GPP, CR and NCP, and the ratio of GPP to CR $(P: R)$

\begin{tabular}{|lcccc|}
\hline & Sep 2001-Aug 2002 & Sep 2002-Aug 2003 & Sep 2003-Jun 2004 & Mean \pm SE \\
\hline GPP $\left(\mathrm{mol} \mathrm{O}_{2} \mathrm{~m}^{-2} \mathrm{yr}^{-1}\right)$ & 45 & 30 & 37 & $37 \pm 4$ \\
$\mathrm{CR}\left(\mathrm{mol} \mathrm{O}_{2} \mathrm{~m}^{-2} \mathrm{yr}^{-1}\right)$ & 35 & 29 & 32 & $32 \pm 2$ \\
$\mathrm{NCP}\left(\mathrm{mol} \mathrm{O}_{2} \mathrm{~m}^{-2} \mathrm{yr}^{-1}\right)$ & 10 & 1 & 5 & $5 \pm 3$ \\
$P: R$ & 1.3 & 1.0 & 1.2 & $1.2 \pm 0.1$ \\
\hline
\end{tabular}

almost equal to the ACD (Fig. 4e). CR may have been reduced during the LP period because of low water temperature. In contrast, the CCD (20\% light depth: 10 to $30 \mathrm{~m}$ ) during the HP period was much shallower than during the LP period (Fig. 7), suggesting that the relative contributions of heterotrophic respiration to algal respiration were greater during the HP period than during the LP period. Therefore, the seasonal variations in CCD imply that the relative contributions of algal and heterotrophic respiration in CR vary seasonally.

NCP was negative in spring 2002, 2003 and 2004. It is thought that net heterotrophy in the water column is due to organic inputs from rivers and/or a temporary imbalance of autotrophic production and heterotrophic consumption. Salinity in spring did not decrease and was $>34$ (Fig. 3b). Therefore, the negative values of NCP in spring may not be dependent on the effect of allochthonous inputs of organic matter. In spring, vertical mixing was still active (Fig. 3a,b), so that phytoplankton production was relatively low because of low light conditions. Sherr \& Sherr (2003) reported that bacterial activity increased with an increase in temperature. In our study, temperature was higher in spring than in winter (Fig. 3a), suggesting that bacterial production was greater in spring than in winter. CR showed a positive correlation with temperature ( $t$-test, $\mathrm{p}<0.001)$. Consequently, the negative values in spring are likely to be due to a temporary imbalance of autotrophic production and heterotrophic consumption.

In 2003, NCP was negative not only in spring, but also in summer. In coastal regions, the inputs of the allochthonous dissolved organic matter (DOM) from rivers may lead to negative NCP (Duarte et al. 2004). Salinity decreased in summer (Fig. 3b), indicating that the influence of river water in Sagami Bay was greater in summer than in winter (Iwata 1985), as mentioned in the 'Introduction'. Allochthonous DOM from rivers may have been discharged into Sagami Bay in summer. Further, GPP in the summer of 2003 was relatively low compared with that in other years because of low solar irradiance (<20 mol quanta $\mathrm{m}^{-2} \mathrm{~d}^{-1}$; Fig. 2). Consequently, the negative NCP in the summer of 2003 is likely to be due to the influx of allochthonous DOM and the low GPP.

During the LP period of each year, GPP and CR were approximately constant, but were very variable during the HP period (Table 2). This implies that the seasonal and annual changes of GPP and CR are dependent on those of the HP period. The mean value $\left(-6 \mathrm{mmol} \mathrm{O}_{2}\right.$ $\mathrm{m}^{-2} \mathrm{~d}^{-1}$ ) of NCP during the HP period over the 3 studied years was negative (Table 2), representing a characteristic of the HP period. Consequently, CR, which exceeds GPP during the HP period, must be supported by organic carbon produced in the past or elsewhere.

The $P: R$ ratio of the community increased with increasing GPP, consistent with results across other aquatic ecosystems (Duarte \& Agustí 1998). The threshold GPP values (LP: $0.4 \mathrm{mmol} \mathrm{O}_{2} \mathrm{~m}^{-3} \mathrm{~d}^{-1}$; HP: 4.1 mmol $\mathrm{O}_{2} \mathrm{~m}^{-3} \mathrm{~d}^{-1}$ ) for metabolic balance (i.e. GPP at $P: R=1$ ) were surprisingly low in comparison with the value $\left(50 \mathrm{mmol} \mathrm{O}_{2} \mathrm{~m}^{-3} \mathrm{~d}^{-1}\right)$ in coastal regions reported by Duarte \& Agustí (1998). The mean value of threshold GPP was $1.4 \mathrm{mmol} \mathrm{O}_{2} \mathrm{~m}^{-3} \mathrm{~d}^{-1}$ over the $3 \mathrm{yr}$ study (Fig. 8), close to the estimate of $1.1 \mathrm{mmol} \mathrm{O}_{2} \mathrm{~m}^{-3} \mathrm{~d}^{-1}$ required to render open ocean communities net autotrophic (Duarte \& Agustí 1998, González et al. 2001). The threshold during the HP period was 10 -fold higher than during the LP period. The value during the $\mathrm{HP}$ period was close to a threshold value $\left(3.95 \mathrm{mmol} \mathrm{O}_{2}\right.$ $\mathrm{m}^{-3} \mathrm{~d}^{-1}$ ) reported for the Mediterranean oligotrophic littoral by Duarte et al. (2004). During the LP period, the threshold GPP value was lower than the mean value, but, during the HP period, it was about 3 times higher than the mean value. This indicates the importance of organic carbon produced in the past or elsewhere in sustaining a relatively high background CR rate during the HP period. Consequently, GPP and CR during the HP period are likely to be supported partially by nutrient and allochthonous DOM from rivers.

In the present study, annual GPP and CR were variable from year to year (Table 3 ). The CV of GPP (20\%) is higher than that of CR (9\%), implying that the variation in annual NCP is greatly dependent on that in annual GPP. Annual GPP was higher than annual CR in the euphotic zone in Sagami Bay during the 3 studied years (Table 3). Consequently, the positive value of annual NCP in Sagami Bay is due to variation in annual GPP. del Giorgio \& Duarte (2002) mentioned that the integrated respiration rate in the 200 to $1000 \mathrm{~m}$ layer should range from 30 to $130 \%$ of the integrated respiration in the 0 to $200 \mathrm{~m}$ layer. The organic carbon exceeding the needs for CR in the euphotic zone may be consumed by organisms living below the euphotic layer of Sagami Bay. 
Acknowledgements. We thank the students, graduate students, the captain and crews of 'Seiyo Maru' of the Tokyo University of Marine Science and Technology and 'Tansei Maru' of the Japan Agency for Marine-Earth Science and Technology for their help in sampling. This study was funded by the Japan Science and Technology Agency as one of the Core Research for Evolutional Science and Technology (CREST) programs. We thank 2 anonymous reviewers for their constructive criticism, which improved this manuscript.

\section{LITERATURE CITED}

Agustí S, Duarte CM (2005) Threshold of gross primary production for planktonic metabolic balance in the Southern Ocean: an experimental test. Limnol Oceanogr 50: $1334-1339$

Agustí S, Satta MP, Mura MP (2004) Summer community respiration and pelagic metabolism in upper surface Antarctic waters. Aquat Microb Ecol 35:197-205

Azam F, Fenchel T, Field JG, Gray JS, Meyer-Reil LA, Thingstad F (1983) The ecological role of water-column microbes in the sea. Mar Ecol Prog Ser 10:257-263

Berman T, Parparov A, Yacobi YZ (2004) Planktonic community production and respiration and the impact of bacteria on carbon cycling in the photic zone of Lake Kinneret. Aquat Microb Ecol 34:43-55

Blight SP, Bentley TL, Lefevre D, Robinson C, Rodrigues R, Rowlands J, Williams PJleB (1995) Phasing of autotrophic and heterotrophic plankton metabolism in a temperate coastal ecosystem. Mar Ecol Prog Ser 128:61-75

Carritt DE, Carpenter JH (1966) Comparison and evaluation of currently employed modifications of the Winkler method for determining dissolved oxygen in seawater; a NASCO report. J Mar Res 24:286-318

del Giorgio PA, Duarte CM (2002) Respiration in the open ocean. Nature 420:379-384

del Giorgio PA, Cole JJ, Cimbleris A (1997) Respiration rates in bacteria exceed phytoplankton production in unproductive aquatic systems. Nature 385:148-151

Duarte CM, Agustí S (1998) The $\mathrm{CO}_{2}$ balance of unproductive aquatic ecosystems. Science 281:234-236

Duarte CM, Agustí S, Vaqué D (2004) Controls on planktonic metabolism in the Bay of Blanes, northwestern Mediterranean littoral. Limnol Oceanogr 49:2162-2170

Findlay S, Pace ML, Lints D, Cole JJ, Caraco NF, Peierls B (1991) Weak coupling of bacteria and algal production in a heterotrophic ecosystem: the Hudson River estuary. Limnol Oceanogr 36:268-278

Geider RJ (1997) Photosynthesis or planktonic respiration? Nature 132:1038

González N, Anadón R, Mouriño B, Sinha B, Escanez J, de Armas D (2001) The metabolic balance of the planktonic community in the North Atlantic Subtropical Gyre: the role of mesoscale instabilities. Limnol Oceanogr 46:946-952

Iwata S (1985) Sagami Bay: physics. In: Oceanographical

Editorial responsibility: Fereidoun Rassoulzadegan (Contributing Editor), Villefranche-sur-Mer, France
Society of Japan (eds) Coastal oceanography of Japanese Islands. Tokai University Press, Tokyo, p 401-409 (in Japanese)

Kamatani A, Ogura N, Nakamoto N, Funakoshi M, Iwata S (1981) Distribution of nutrients in Sagami Bay during 1971-1973. Bull Jpn Soc Sci Fish 47:1493-1498

Kanda J, Fujiwara S, Kitazato H, Okada Y (2003) Seasonal and annual variation in the primary production regime in the central part of Sagami Bay. Prog Oceanogr 57:17-29

Najjar RG, Keeling RF (1997) Analysis of the mean annual cycle of the dissolved oxygen anomaly in the World Ocean. J Mar Syst 55:117-151

Oudot C, Gerard R, Morin P, Gningue I (1988) Precise shipboard determination of dissolved oxygen (Winkler procedure) for productivity studies with a commercial system. Limnol Oceanogr 33:146-150

Parsons TR, Maita Y, Lalli CM (1984) A manual of chemical and biological methods for seawater analysis. Pergamon Press, Oxford

Serret P, Fernández E, Sostres JA, Anadón R (1999) Seasonal compensation of microbial production and respiration in a temperate sea. Mar Ecol Prog Ser 187:43-57

Serret P, Robinson C, Fernández E, Teira E, Tilstone G (2001) Latitudinal variation of the balance between plankton photosynthesis and respiration in the eastern Atlantic Ocean. Limnol Oceanogr 46:1642-1652

Sherr BF, Sherr EB (2003) Community respiration/production and bacterial activity in the upper water column of the central Arctic Ocean. Deep-Sea Res 50:529-542

Sherr EB, Sherr BF (1996) Temporal offset in oceanic production and respiration processes implied by seasonal changes in atmospheric oxygen: the role of heterotrophic microbes. Aquat Microb Ecol 11:91-100

Smith EM, Kemp WM (2001) Size structure and the production/respiration balance in a coastal plankton community. Limnol Oceanogr 46:473-485

Steemann-Nielsen E (1952) The use of radioactive carbon $\left({ }^{14} \mathrm{C}\right)$ for measuring organic production in the sea. $\mathrm{J}$ Cons Int Explor Mer 18:117-140

Suzuki R, Ishimaru T (1990) An improved method for the determination of phytoplankton chlorophyll using N,Ndimethylformamide. J Oceanogr 46:190-194

Takahashi M, Koike I, Ishimaru T, Saino T, Furuya K, Fujita Y, Hattori A, Ichimura S (1980) Upwelling plumes in Sagami Bay and adjacent water around the Izu Island, Japan. J Oceanogr Soc Jpn 36:209-216

Williams PJleB (1993) On the definition of plankton terms. ICES Mar Sci Symp 197:9-19

Williams PJleB (1998) The balance of plankton respiration and photosynthesis in open oceans. Nature 394:55-57

Williams PJleB, Purdie DA (1991) In vitro and in situ derived rates of gross production, net community production and respiration of oxygen in the oligotrophic subtropical gyre of the North Pacific Ocean. Deep-Sea Res 38:891-910

Williams PJleB, Morris PJ, Karl DM (2004) Net community production and metabolic balance at the oligotrophic ocean site, station ALOHA. Deep-Sea Res 51:1563-1578

Submitted: September 15, 2005; Accepted: February 23, 2006 Proofs received from author(s): August 12, 2006 